\title{
The Possibility of the Inert Gas Generator Environmental Operation Mode Utilization on Long Range 2 Oil Tankers During Discharge Operation
}

\section{Mogućnost primjene ekološki prihvatljivog načina rada generatora inertnog plina na Long Range 2 tankerima tijekom iskrcaja}

\author{
Marko Milković \\ OSM Bergen \\ E-mail: marko.milkovic@osm.no
}

\author{
Ivica Krmek \\ University of Dubrovnik \\ Maritime Department \\ E-mail: ivica.krmek@unidu.hr
}

\author{
Miho Kristić \\ University of Dubrovnik \\ Maritime Department \\ E-mail: miho.kristic@unidu.hr
}

\author{
Miljen Sirotić \\ University of Rijeka \\ Faculty of Maritime Studies \\ E-mail:miljensirotić@hotmail.com
}

DOI 10.17818/NM/2021/2.9

UDK 629.543:621.43.068

Professional paper / Stručni rad

Paper accepted / Rukopis primljen: 9. 9. 2020

\section{Summary}

Long Range 2 tankers are the largest ships used for the transportation of petroleum products. Although more than 400 Long Range 2 tankers are navigating the world's sea, many of the terminals, at which these ships discharge their cargo, do not utilize their discharging capacity to the full extent. This is due to the technological obsolescence of the terminal and the fact that these terminals are primarily designed to accommodate smaller tankers, such as Medium Range and Long Range 1 tankers. The reduced discharge capacity leads to longer ship stay in the port and increased air pollution due to the release of inert gas into the atmosphere since terminals unnecessarily insist on the continuous operation of the inert gas generator. This paper explains a possible solution to this problem by using environmentally friendly START/STOP operation mode of an inert gas generator using methods of analysis and synthesis, comparative methods and elements of the mathematical method. Environmentally friendly operation mode requires minimal modification of the software program and it is very easy to perform. This mode has a positive effect on reducing overall gas emissions and significant fuel savings.

\section{Sažetak}

Tankeri Long Range 2 najveći su brodovi koji se koriste za prijevoz naftnih derivata. Iako više od 400 tankera Long Range 2 plovi svjetskim morima, mnogi terminali na kojima ti brodovi iskrcavaju svoj teret ne koriste se u potpunosti svojim kapacitetom iskrcaja. Razlog je tomu tehnološka zastarjelost terminala i činjenica da su oni prvenstveno dizajnirani za prihvat manjih tankera, poput Medium Range i Long Range 1. Smanjeni kapacitet iskrcaja dovodi do dužeg zadržavanja broda u luci i povećanog zagađenja zraka zbog ispuštanja inertnog plina u atmosferu jer terminali nepotrebno inzistiraju na kontinuiranom radu generatora inertnog plina. $U$ radu predstavlja se moguće rješenje ovog problema primjenom ekološki prihvatljivog načina rada START/STOP generatora inertnog plina korištenjem metodama analize i sinteze, usporednih metoda i elemenata matematičke metode. Ekološki prihvatljiv način rada zahtijeva minimalne izmjene softverskog programa i vrlo je jednostavan za primjenu. Ovaj način rada pozitivno utječe na smanjenje ukupnih emisija plina i značajnu uštedu goriva.

\section{KEY WORDS \\ START/STOP operation of IGS \\ air pollution \\ tanker terminal}

\section{INTRODUCTION / Uvod}

An important part of the transport chain of crude oil and derivatives from producers to final consumers are the terminals for their transshipment. These terminals can be divided into conventional and offshore terminals; the latter being mainly used for loading crude oil into larger tankers.

Conventional tanker terminals differ in their purpose and size. When designing and building them, the following must be taken into account: distance from populated areas, waterway from the open sea to berths, the impact of sea currents, sea depth, protection of berths from wind, configuration of the coast and surrounding terrain, increase of storage and transshipment capacities and simplicity of pollution limitation in case of accidental discharge of cargo into the sea [3].

The number of berths in conventional tanker terminals varies from one to several dozen. Depending on their purpose and storage capacity, there are different numbers of storage tanks at the terminals. The capacity of tanks depends on the type of product they are designed for. There are terminals that are made only for transshipment of crude oil but are very rare. Most often the terminals are combined for transshipment and storage of crude oil with various derivatives. Terminals with a large number of berths and tank capacity are, in principle, 
combined. Due to the harmful impact of oil and derivatives on people and the environment, transshipment terminals are located outside urban areas.

Tankers for the transport of petroleum products (product tankers) differ in their construction from crude oil tankers. Their main difference is in the size and construction of the cargo system, including cargo pipelines. Product tankers are more complex and have the ability to transport up to six different cargoes. They are smaller in size, and their largest size is LR2 (long range tanker) [5].

Table 1 shows the sizes of the product tankers.

Table 1 Product tankers sizes

Tablica 1. Veličine tankera za prijevoz naftnih derivata

\begin{tabular}{|c|c|}
\hline PRODUCT TANKER CLASS & CAPACITY - dwt \\
\hline HANDY & $10000-29999$ \\
\hline MEDIUM RANGE & $30000-54999$ \\
\hline PANAMAX & $55000-74999$ \\
\hline LONG RANGE 1 & $75000-79999$ \\
\hline LONG RANGE 2 & $80000-119999$ \\
\hline
\end{tabular}

Source: Authors

It is important to note that the primary purpose of LR1 and LR2 tankers is to transport petroleum products, but they can also transport crude oil depending on the world's market demand. The cargo system of the LR 2 tanker is specially designed to enable efficient cleaning of cargo tanks. Cargo pumps are immersed in each tank. Cargo heaters are located on the deck and if it is necessary to heat the cargo this is done by slow circulation of the cargo through the heaters using cargo pumps. Owing to this, cargo tanks washing with SCANJET tank cleaning machines is very efficient and in most cases there is no need for manual inspection of cargo tanks. The tanks are also equipped with a super striping system that allows the tank to dry perfectly so that there is no need for the crew to enter the tank.

In this paper, the model of the tanker terminal for unloading of the petroleum products from LR2 tankers was used. Terminal has two berths, each with two cargo connections. Berths can accept tankers up to the maximum length of $250 \mathrm{~m}$ (LR2) and are characterized by: maximum tanker capacity (dwt) $120000 \mathrm{t}$, berth depth $13.0 \mathrm{~m}$, minimum depth below the keel of the ship (UKC) 0.6 $\mathrm{m}$, maximum draft of the ship $12.4 \mathrm{~m}$ (plus the value of high water) and the minimum parallel length of the ship's side on the waterline, measured from the center of the cargo unloading connections (cargo arms) - $30.0 \mathrm{~m}$ in the direction of the bow and stern. For tankers that do not meet these requirements the terminal will make a special risk assessment on the case by case basis.

During the tanker stay at the terminal, the ship's crew must follow the instructions prescribed by the terminal: use the minimum number of hydraulic units to drive the cargo pumps during unloading, minimize the use of engine room fans, minimize heating of fuel tanks, i.e. minimize steam boiler operation, reduce operation of unnecessary systems, reduce the load of the diesel generator and optimize the operation of the Inert Gas Generator (IGG) so that as little inert gas is released into the environment as possible. Therefore, it is crucial to develop an economical inert gas management system with the purpose of minimizing environmental pollution.

The development and modernization of tanker terminals does not follow an increase in the total tonnage of LR2 tankers.
The traditional way of using the inert gas system, during the unloading of these tankers at reduced capacity, is not a good solution because there is a big problem of environmental pollution. Therefore, it is necessary to find a new and better solution that can ensure a large reduction in gas emissions. To achieve this, the START/STOP mode of operation of the IGG during unloading would be more ecologically justified, which can be proven by applying the methods of analysis and synthesis, comparative methods and elements of the mathematical method.

\section{MATERIALS AND METHODS / Materijali i metode}

One feature of the LR 2 tanker is that inert gas is produced in a purpose built IGG. Cargo pumps can be driven either by the Norwegian manufacturer Frank Mohn (FRAMO) that utilizes hydraulic system or by electrically driven cargo pumps manufactured by the Dutch manufacturer MARFLEX. In this paper, the FRAMO hydraulic system and the Wartsilla Moss IGG are taken as examples.

\subsection{Inerting of LR2 tanker cargo tanks / Inertiranje tankova tereta na tankerima LR2}

Submersible centrifugal pumps driven by FRAMO (Frank Mohn Norwagien manufacturer of cargo systems used on most LR2 tankers) hydraulic units are used for unloading. During unloading, the cargo pumped out of the tanks is replaced by inert gas. The inert gas pressure in the tanks must be kept positive at all times, at least $100 \mathrm{mmWC}$. A feature of the LR2 tanker is that inert gas is produced in an IGG, installed only for this purpose.

Inerting of cargo tanks during unloading can be done in two ways: by inert gas from the tanker terminal or by inert gas produced in the ship's IGG. A small number of terminals have the infrastructure that allows inerting ship cargo tanks from the terminal tanks, so it is necessary to use inert gas produced on board. A Hamworthy Moss generator is commonly used to produce inert gas on the LR2 tanker.

A basic schematic diagram of the IGG is shown in Figure 1. The main parts of an IGG are burner, scrubber, demister and fans [7].

Inert gas is obtained by burning diesel fuel with low sulfur content (MGO <0.1\% S) in the generator furnace. Two electric gear pumps are used to supply fuel. The pump supplies fuel to the ignition burner and the main burner. The air required to burn fuel is supplied by one of the two electric fans installed.

Exhaust gases flow through the combustion chamber towards its bottom where they come in contact with a large amount of seawater. Seawater cleans combustion gases from soot particles and other impurities. This process takes place in the part of the generator that is called purifier. Contaminated seawater from the purifier flows outside the ship by gravity.

An electric centrifugal pump is used to supply seawater. In addition to exhaust gas purification, seawater is also used to cool the combustion chamber. The combustion chamber has a mantle through which seawater flows and thus cools the inner walls of the combustion chamber.

After the purifier, the inert gas flows over the demister which prevents flowing of the water droplets with a stream of the inert gas and exits from the generator on the top of the tower. On the tower top there is a pipe which supplies inert gas to the deck.

IGG can operate in automatic and manual operation mode. 


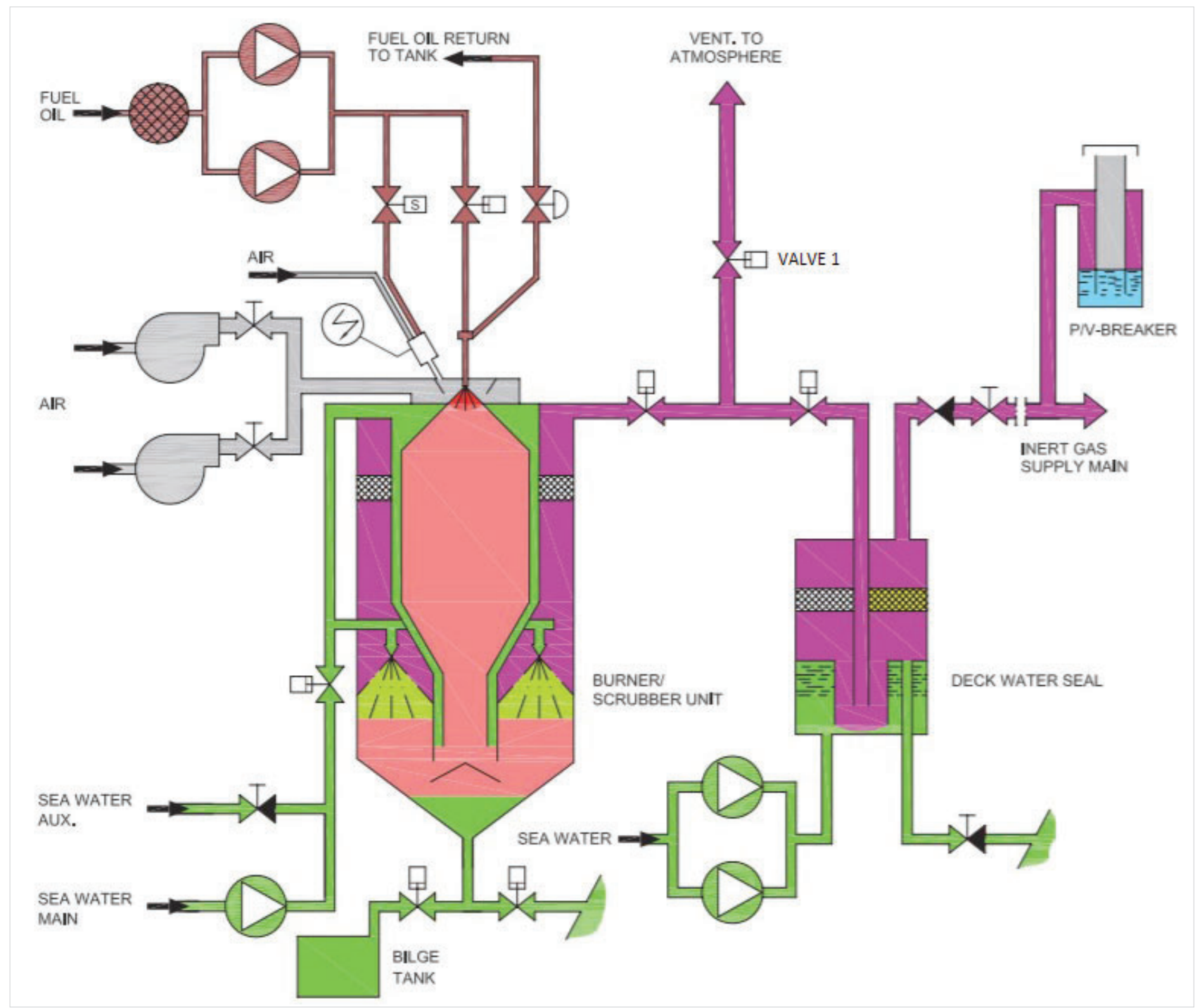

Figure 1 Working principle of Hamworthy Moss's IGG installation [7] Slika 1. Princip rada instalacije IGG Hamworthy Moss [7]

During manual operation, the generator operates at a constant capacity. During automatic operation, the capacity of the IGG changes depending on the pressure in the deck pipeline.

Each time valve 1 is opened, the inert gas is released into the atmosphere, which represents a significant loss of energy and unnecessary environmental pollution. Energy loss is the combustion of fuel in an IGG to produce an inert gas that is released into the atmosphere under conditions of high pressure in the deck pipeline. This causes a great economic loss.

Environmental pollution caused by the emission of harmful gases from the combustion of hydrocarbons on ships has been recognized as a major problem in the recent years, so the International Maritime Organization (IMO) in 2011 has brought the resolution MEPC 304(72) which regulates that by 2050 greenhouse gas emissions from ships will be reduced by $50 \%$ compared to 2008 level [2]. One of the solutions that can help reduce greenhouse gas emissions to the environment is the application of the START/STOP mode of IGG operation.

\subsection{Cargo tanks inerting by means of IGG / Inertiranje tankova tereta IGG-om}

Equipment for the production of inert gas on tankers shall be designed with a capacity greater than at least $25 \%$ of the maximum unloading capacity. The capacity of the cargo pumps is designed for the nominal lifting height. If the lifting height is lower, the pump load may exceed its rated capacity. This is one of the reasons why inert gas production is designed with at least $25 \%$ reserve capacity. When LR2 tankers transport crude oil or heavy fuel (which is very rare), the unloading capacity is higher and generally amounts to 4000 to $8000 \mathrm{m3} / \mathrm{h}$. When transporting oil derivatives, the unloading capacity is much smaller, ranging from 800 to $2500 \mathrm{~m} 3 / \mathrm{h}$ and in some instances as low as $500 \mathrm{~m} 3 / \mathrm{h}$. The main reason is that the infrastructure at the tanker terminals is not adapted to that size of ships, but it was primarily intended for smaller ships such as medium range tanker (MR) and LR1 tankers.

Most tanker terminals request that the IGG operates continuously in automatic mode from the beginning to the end of the cargo unloading and that the inert gas pressure of $800 \mathrm{mmWG}$ is kept constant in the cargo tanks. In conditions of reduced unloading capacity less than $40 \%$, which corresponds to a flow of $3600 \mathrm{~m} 3 / \mathrm{h}$, the IGG releases a large part of the gases into the environment. The smaller the unloading capacity is, the higher the inert gas emissions into the environment are. This contributes to high environmental pollution and unnecessary fuel consumption. 
Table 2 IGG Fuel consumption, $\mathrm{NO}_{x}$ and $\mathrm{CO}_{2}$ emissions depending on unloading capacity Tablica 2. Potrošnja goriva IGG-a, emisije $\mathrm{NO}_{x} i \mathrm{CO}_{2}$ ovisno o kapacitetu iskrcaja

\begin{tabular}{|c|c|c|c|c|c|c|}
\hline $\begin{array}{l}\text { Unloading capacity } \\
\qquad\left(\%-\mathrm{m}^{3} / \mathrm{h}\right)\end{array}$ & $\begin{array}{l}\text { IGG capacity } \\
\left(\%-\mathrm{m}^{3} / \mathrm{h}\right)\end{array}$ & $\begin{array}{l}\text { IGG fuel consumption } \\
(\mathrm{kg} / \mathrm{h})\end{array}$ & $\begin{array}{l}\text { Unloading time } \\
\text { (h) }\end{array}$ & $\begin{array}{l}\text { NOx emission to } \\
\text { environment } \\
\text { (kg/unloading) }\end{array}$ & $\begin{array}{l}\mathrm{CO}_{2} \text { emission to } \\
\text { environment } \\
\text { (t/unloading) }\end{array}$ & $\begin{array}{l}\text { Unnecessary } \\
\text { burnt fuel (kg) }\end{array}$ \\
\hline $100-9000$ & $62-9000$ & 664 & 14.9 & 0 & 0 & 0 \\
\hline $90-8100$ & $56-8100$ & 660 & 16.6 & 0 & 0 & 0 \\
\hline $80-7200$ & $50-7200$ & 535 & 18.6 & 0 & 0 & 0 \\
\hline $70-6300$ & $43-6300$ & 465 & 21.3 & 0 & 0 & 0 \\
\hline $60-5400$ & $37-5400$ & 398 & 24.9 & 0 & 0 & 0 \\
\hline $50-4500$ & $31-4500$ & 332 & 30.0 & 0 & 0 & 0 \\
\hline $40-3600$ & $25-3600$ & 267 & 37.3 & 0 & 0 & 0 \\
\hline $30-2700$ & $19-2700$ & 199 & 49.7 & 147.9 & 10.84 & 3380 \\
\hline $20-1800$ & $12-1800$ & 132 & 76.0 & 449.0 & 33.0 & 10260 \\
\hline $10-900$ & $6-900$ & 66 & 149.0 & 1291 & 94.60 & 29500 \\
\hline
\end{tabular}

Source: Authors

Table 2 ilustrates the data on fuel consumption, Nitrogen Oxides $\left(\mathrm{NO}_{\mathrm{x}}\right)$ and Carbon Dioxide $\left(\mathrm{CO}_{2}\right)$ emissions depending on the unloading capacity. This table shows that the release of inert gas into the environment occurs when the unloading capacity is less than $40 \%$. A factor of $3.206 \mathrm{t} / \mathrm{t}$ of light diesel fuel consumed was used to calculate $\mathrm{CO}_{2}$ emissions to the environment [6], and a factor of $43.76 \mathrm{~kg} / \mathrm{t}$ of fuel consumed was applied to $\mathrm{NO}_{x}$ emissions [4].

From a safety point of view, there is no justification for the continuous operation of an IGG. A possible solution to this problem is to apply the START/STOP mode of its operation.

\section{CASE STUDY / Studija slučaja}

The continuous operation mode of the IGG during loading is a standard practice regardless of the unloading capacity at the tanker terminals. This practice is fully justified during the unloading of MR and LR1 tankers as they are designed with lower discharging capacities, however, during the unloading of LR2 tankers at most terminals this practice is not justified from a safety, economic or environmental aspect. In the continuation of this paper, a possible solution to this problem is analysed.

\subsection{IGG START/STOP operation mode during unloading / START/STOP način rada IGG-a tijekom iskrcaja}

START/STOP mode contributes to reducing emissions of harmful gases into the environment and to reducing the environmental footprint. Therefore, this operational mode can be defined as an ecological or environmentally friendly mode.

An environmentally friendly mode of operation of the generator can be performed in two ways: manually with 50\% fixed capacity, so that the person in charge of unloading turns on the generator when the inert gas pressure in cargo tanks is reduced to $400 \mathrm{mmWG}$, and turns off when the inert gas pressure reaches $1100 \mathrm{mmWG}$, or environmentally friendly automatic operation. To enable an environmentally friendly operation mode, it is necessary to make simple modification of the IGG operating software by defining the values of the inert gas pressure and capacity at which the generator will automatically turn on and off. The recommended value of the starting pressure is $400 \mathrm{mmWG}$, stopping $1100 \mathrm{mmWG}$ (generator capacity varies from $25 \%$ to $50 \%$, provided that the generator is stopped and started at a capacity of 25\%).

If the cargo tanks are loaded up to $98 \%$ of the maximum capacity, which in this example would be $134064 \mathrm{~m}^{3}$, while the empty space of the cargo tanks is $2736 \mathrm{~m}^{3}$, it is recommended to start with the application of environmentally friendly automatic operation after unloading a certain amount of cargo (which depends on the unloading capacity), in order to avoid frequent shutdowns of the IGG at the beginning of the unloading. The recommended time between stopping and restarting is about $30 \mathrm{~min}$.

The time between stopping and starting the IGG in environmentally friendly automatic operation can be calculated by means of the equation (1):

$p V=\dot{m} R T t$

where:

$\mathrm{p}$ - inert gas pressure, $\mathrm{Nm}^{-2}$

$\mathrm{V}$ - inert gas volume, $\mathrm{m}^{3}$

$\dot{m}$ - inert gas mass flow, $\mathrm{kgs}^{-1}$

$\mathrm{R}$ - gas constant, $\mathrm{Jkg}^{-1} \mathrm{~K}^{-1}$

$\mathrm{T}$ - inert gas temperature, $\mathrm{K}$

$\mathrm{t}$ - time, $\mathrm{s}$

From the equation (1) the time and mass flow can be calculated as follows:

$t=\frac{p V}{\dot{m} R T}$

$\dot{m}=\rho Q$

where:

$\rho$ - inert gas density, $\mathrm{kgm}^{-3}$

$\mathrm{Q}$ - flow volume - cargo unloading capacity, $\mathrm{m}^{3} \mathrm{~h}^{-1}$

Time in minutes can be calculated as follows:

$t=60 \frac{p V}{\rho Q R T}, \min$

An average inert gas temperature during inerting process is $40^{\circ} \mathrm{C}$ or $313 \mathrm{~K}$, density $\rho$ is $1,044 \mathrm{kgm}^{-3}$ and $\mathrm{R}$ is $282 \mathrm{Jkg}^{-1} \mathrm{~K}^{-1}$.

Given that the value of the product of three members in the denominator of the previous equation ( $\rho \mathrm{RT}$ ) of data in the real value of the inert gas approximately equals 100,000 $\mathrm{Nm}^{-2}$, to calculate the time between the IGG start and stop in minutes the adapted equation was used:

$t=60 \mathrm{~V} \frac{p_{1}-p_{2}}{Q}, \min$

where:

$\mathrm{t}$ - Time between IGG start and stop (min);

$\mathrm{V}$ - Volume of cargo tanks void space (empty space above cargo) after IGG stop $\left(\mathrm{m}^{3}\right)$; 
$\mathrm{p}_{1}$ - Inert gas pressure after IGG stop (bar) - defined as a constant of 0.11 bar;

$\mathrm{p}_{2}$ - Inert gas pressure before start of IGG (bar) - defined as a constant of 0.04 bar;

$\mathrm{Q}$ - Unloading capacity $\left(\mathrm{m}^{3} / \mathrm{h}\right)$.

The following examples show the calculation of the environmentally friendly operation mode starting time.

Example 1: Cargo tanks loaded to the $98 \%$ of capacity, required unloading capacity $900 \mathrm{~m}^{3} / \mathrm{h}$.

$\mathrm{t}=2736 \mathrm{~m}^{3} \times \frac{0.11 \text { bar }-0.04 \mathrm{bar}}{900 \mathrm{~m} 3} \times 60(\mathrm{~min})=13 \mathrm{~min}$

Example 2: Cargo tanks loaded to the $98 \%$ capacity, required unloading capacity $900 \mathrm{~m}^{3} / \mathrm{h}$. The environmentally friendly mode of operation of the IGG starts after $3700 \mathrm{~m}^{3}$ of cargo has been unloaded:

$\mathrm{t}=60(\mathrm{~min}) \times 6436 \mathrm{m3} \times \frac{0.11 \mathrm{bar}-0.04 \mathrm{bar}}{900 \mathrm{~m} 3}=30 \mathrm{~min}$

Example 3: Cargo tanks loaded to $98 \%$ capacity, required unloading capacity $1800 \mathrm{~m}^{3} / \mathrm{h}$ :

$\mathrm{t}=60(\mathrm{~min}) \times 2736 \mathrm{~m} 3 \times \frac{0.11 \text { bar }-0.04 \mathrm{bar}}{1800 \mathrm{~m} 3}=6.5 \mathrm{~min}$

Example 4: Cargo tanks loaded to $98 \%$ capacity, required unloading capacity $1800 \mathrm{~m}^{3} / \mathrm{h}$. Start with the environmentally friendly mode of operation of the IGG after $10000 \mathrm{~m}^{3}$ of cargo has been unloaded:

$\mathrm{t}=60(\mathrm{~min}) \times 12736 \mathrm{~m} 3 \times \frac{0.11 \mathrm{bar}-0.04 \mathrm{bar}}{1800 \mathrm{~m} 3}=30 \mathrm{~min}$

Example 5: Cargo tanks loaded to $98 \%$ capacity, required unloading capac $2700 \mathrm{~m}^{3} / \mathrm{h}$. Start with the environmentally friendly mode of operation of the IGG after $8100 \mathrm{~m}^{3}$ of cargo has been unloaded:

$\mathrm{t}=60(\mathrm{~min}) \times 10836 \mathrm{~m} 3 \times \frac{0.11 \mathrm{bar}-0.04 \mathrm{bar}}{2700 \mathrm{~m} 3}=17 \mathrm{~min}$

Example 6: Cargo tanks loaded to $98 \%$ capacity, required unloading capacity $2700 \mathrm{~m}^{3} / \mathrm{h}$. Start with the environmentally friendly mode of operation of the IGG after $16500 \mathrm{~m}^{3}$ of cargo has been unloaded:

$$
\mathrm{t}=60(\mathrm{~min}) \times 19236 \mathrm{~m} 3 \times \frac{0.11 \text { bar }-0.04 \text { bar }}{2700 \mathrm{~m} 3}=30 \mathrm{~min}
$$

Examples 1, 3 and 5 show the calculation of the time in which the minimum of 30 minutes between stopping and restarting the IGG is not satisfied.

Based on the calculation of the initial start time of the ecological mode of operation of the IGG, values presented in Table 3 are obtained.

If the time delay of the application of the environmentally friendly operation mode is taken into account until the appropriate empty space in the cargo tanks is reached, the reduction of $\mathrm{NO}_{x}$ and $\mathrm{CO}_{2}$ emissions at $10 \%, 20 \%$ and $30 \%$ of the unloading capacity can be calculated as per Table 4 .

The calculation was made for continuous operation of the IGG at the minimum allowable capacity of $25 \%$.

\section{RESULTS / Rezultati}

Figure 2 shows the dependence of $\mathrm{CO}_{2}(\mathrm{t})$ emissions on the unloading capacity of the cargo during START/STOP operation mode of IGG.

Figure 3 shows the dependence of $\mathrm{NO}_{x}(\mathrm{~kg})$ emissions on the unloading capacity of the cargo during START/STOP operation mode of IGG.

For a comparison of the GHG emissions to the environment, GHG emission for a new car with gasoline engine produced in 2018 can be used. This car emits $120.4 \mathrm{gr} / \mathrm{km}$ of $\mathrm{CO}_{2}$ [1] and makes on average $20000 \mathrm{~km}$ per year.

If the LR2 tanker unloads its full cargo, with an unloading capacity of $900 \mathrm{~m} 3 / \mathrm{h}$, and if the IGG operates on continuous mode, LR2 releases the amount of pollution equivalent to 38 cars in a year or 2237 cars, just during the ship's stay at the terminal for one cargo unloading of 149 hours.

Table 3 Calculation of the initial time of the IGG START/STOP operation mode Tablica 3. Izračun početnog vremena načina rada IGG-a START/STOP

\begin{tabular}{|c|c|c|c|c|}
\hline $\begin{array}{c}V \text { - Void space volume at } \\
\text { beginning of START/STOP } \\
\text { operation }\left(\mathrm{m}^{3}\right)\end{array}$ & $\begin{array}{c}\text { IG STOP-START Pressure } \\
\text { difference } \\
\mathrm{p}_{1-\mathrm{p}_{2}} \\
0.11-0.04\end{array}$ & $\begin{array}{l}\text { Q - required unloading } \\
\text { capacity } \\
\left(\mathrm{m}^{3} / \mathrm{h}\right)\end{array}$ & $\begin{array}{l}\mathrm{T} \text { - calculated time } \\
\text { between IGG stop and } \\
\text { start } \\
\text { (h) }\end{array}$ & $\begin{array}{l}\text { Initial time of START/STOP } \\
\text { operation mode after start } \\
\text { of cargo unloading } \\
\text { (h) }\end{array}$ \\
\hline 2736 & 0.07 & 900 & 13 & \\
\hline 6436 & 0.07 & 900 & 30 & 4.1 \\
\hline 2736 & 0.07 & 1800 & 6.5 & \\
\hline 12736 & 0.07 & 1800 & 30 & 5.5 \\
\hline 2736 & 0.07 & 2700 & 4 & \\
\hline 19236 & 0.07 & 2700 & 30 & 6.1 \\
\hline
\end{tabular}

Source: Authors

Table 4 Calculation of $\mathrm{NO}_{x}$ and $\mathrm{CO}_{2}$ emission reductions in the IGG START/STOP operation mode [Authors] Tablica 4. Izračun smanjenja emisija $\mathrm{NO}_{x}$ i $\mathrm{CO}_{2}$ u načinu rada IGG-a START/STOP [Autori]

\begin{tabular}{|c|c|c|c|c|c|c|}
\hline $\begin{array}{l}\text { Unloading capacity } \\
\qquad \mathrm{Q}\left(\%-\mathrm{m}^{3} / \mathrm{h}\right)\end{array}$ & $\begin{array}{l}\text { IGG continuous } \\
\text { operation } \mathrm{CO}_{2} \\
\text { emissions } \\
\text { (t) }\end{array}$ & $\begin{array}{l}\text { IGG START/STOP } \\
\text { operation mode - } \\
\mathrm{CO}_{2} \text { emisssions } \\
(\mathrm{t})\end{array}$ & $\begin{array}{l}\text { TOTAL REDUC- } \\
\text { TION OF } \mathrm{CO}_{2} \\
\text { EMISSIONS }(\mathrm{t})\end{array}$ & $\begin{array}{l}\text { IGG continuous } \\
\text { operation } \mathrm{NO}_{\mathrm{x}} \\
\text { emissions } \\
(\mathrm{kg})\end{array}$ & $\begin{array}{l}\text { IGG START/STOP } \\
\text { operation mode } \\
\mathrm{NO}_{x} \text { emissions } \\
(\mathrm{kg})\end{array}$ & $\begin{array}{l}\text { TOTAL REDUC- } \\
\text { TION OF NOx } \\
\text { EMISSION }(\mathrm{kg})\end{array}$ \\
\hline $10-900$ & 94.6 & 2.6 & 92.0 & 1291.0 & 36.0 & 1255.0 \\
\hline $20-1800$ & 33.0 & 2.4 & 30.6 & 449.0 & 32.5 & 416.5 \\
\hline $30-2700$ & 10.8 & 1.3 & 9.5 & 147.9 & 18.0 & 129.9 \\
\hline
\end{tabular}

Source: Authors 


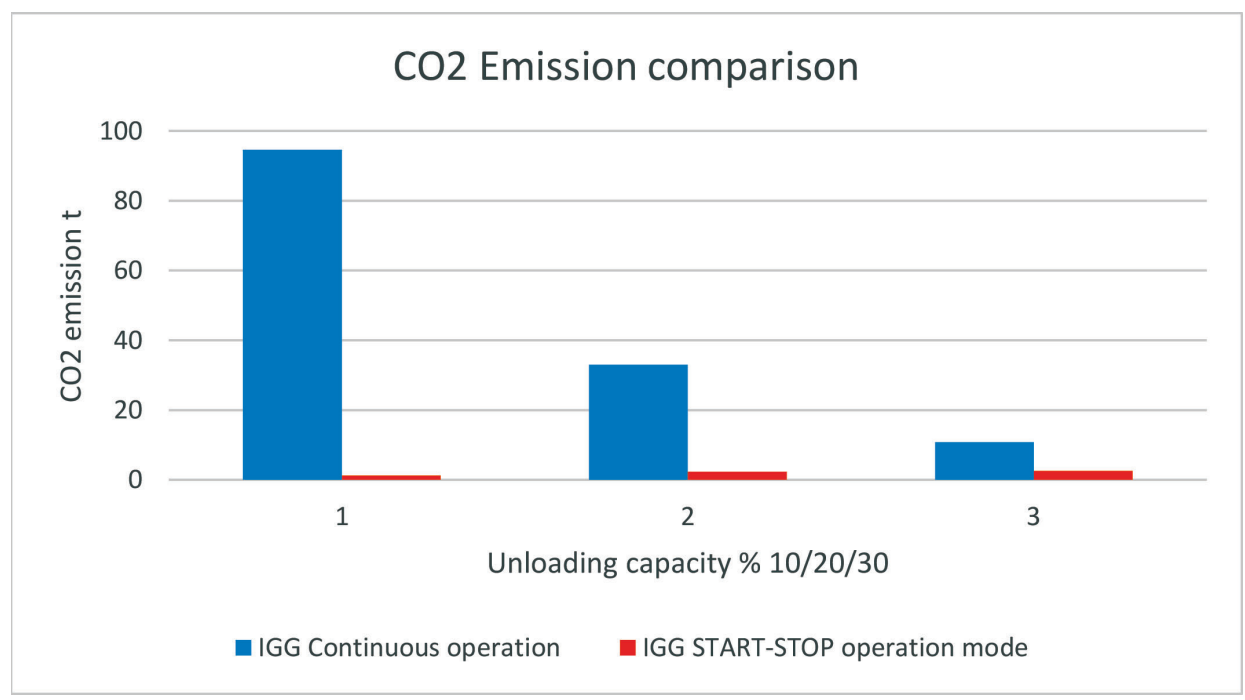

Figure 2 Graphic comparison of $\mathrm{CO}_{2}$ IGG emissions

Source: Authors Slika 2. Grafička usporedba emisija $\mathrm{CO}_{2}$ iz IGG-a

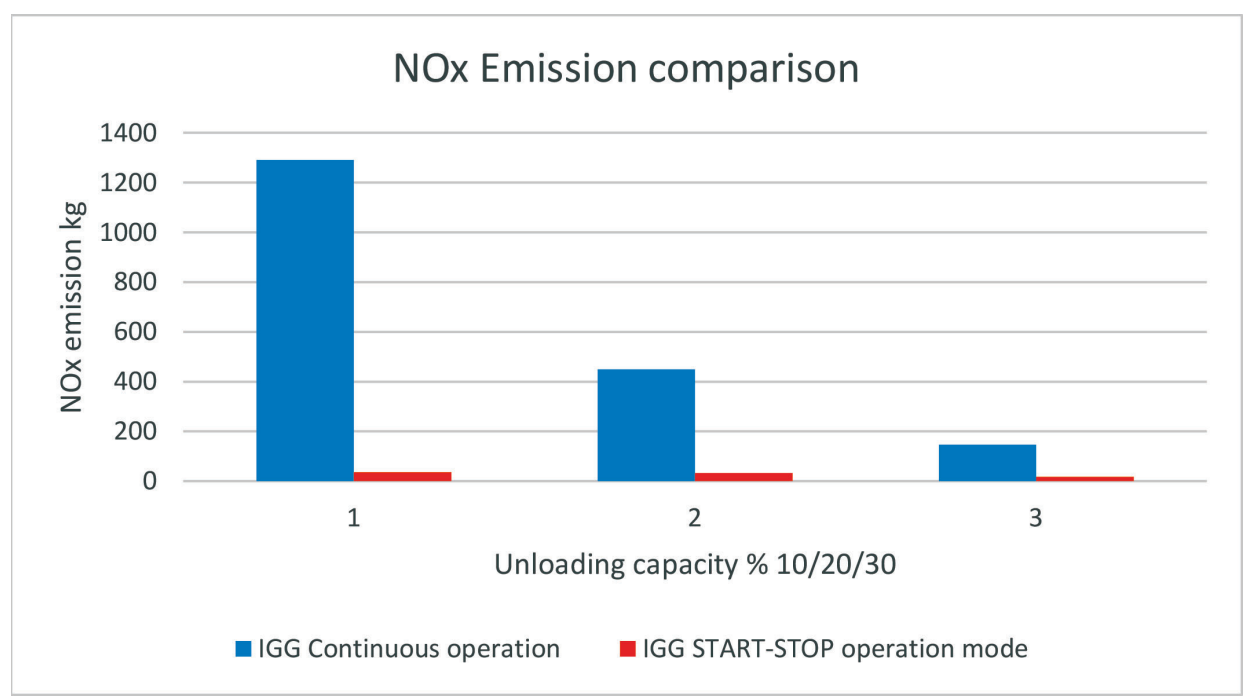

Figure 3 Graphic comparison of $\mathrm{NO}_{x}$ IGG emissions

Source: Authors

Slika 3. Grafička usporedba emisija NOx iz IGG-a

\section{CONCLUSION / Zaključak}

Due to the growing number of LR2 tankers on the market in recent years, an increasing amount of petroleum products are transported by this type of ship instead of MR and LR1 ships. The reason for this is the change in direction of the sea transport of petroleum products and the increase in the amount of derivatives that are transported over long distances. Transporting oil products on LR2 tankers is significantly more economical per ton-mile compared to smaller ships. Since the development and modernization of tanker terminals is not aligned with an increase in the total tonnage of LR2 tankers, there is a problem of environmental pollution due to the release of inert gas during unloading of tankers with reduced capacity. Therefore, the traditional way of using an inert gas system during unloading at reduced capacity is not a good solution. A much better solution can be achieved by START/STOP operation mode of the IGG during unloading which ensures a large reduction in emissions of harmful gases into the environment and thus is ecologically justified as presented by the methods of analysis and synthesis, comparative method and mathematical method elements.

\section{REFERENCES / Literatura}

[1] EU Comission - Regulacion EC 443/2009, Reducing CO2 emissions from passanger cars before 2020, released 23 April 2009. https://ec.europa.eu/ clima/policies/transport/vehicles/cars_en [accessed 1/7/2020]

[2] IMO GHG Emissions: Second GHG study 2009. http://www.imo.org/en/OurWork/Environment/Pollution Prevention/AirPollution/Pages/GHG-Emissions.aspx [accessed 19/7/2020]

[3] Oil Companies International Marine Forum (OCIMF): Manning at Conventional Marine Terminals, 1 June 2008. https://www.ocimf.org/publications/information-papers/manning-at-conventional-marine-terminals [accessed 15/7/2020]

[4] SSB Statistics Norway: Emission to air 1990-2018, 1 November 2018. https:// www.ssb.no/en/natur-og-miljo/statistikker/klimagassn/aar/2019-11-01 [accessed 26/7/2020]

[5] US Energy Information Administration. https://www.eia.gov/todayinenergy/detail.php?id=17991 [accessed 15/4/2020]

[6] Verifavia Shipping Emissions. https://www.verifavia-shipping.com/shipping-carbon-emissions-verification/faq-which-emission-factors-shall-beused-110.php [accessed 26/7/2020]

[7] Wartsila Moss Inert Gas System for Tankers, 2013. https://www.wartsila. $\mathrm{com} / \mathrm{marine} / \mathrm{build} / \mathrm{gas}$-solutions/inert-gas/wartsila-moss-inert-gas-generators-for-tankers [accessed 15/7/2020] 